Terbit online pada laman : http://teknosi.fti.unand.ac.id/

Jurnal Nasional Teknologi dan Sistem Informasi

ISSN (Print) 2460-3465 | ISSN (Online) 2476-8812 |

Studi Kasus

\title{
Identifikasi Faktor Resistansi Guru Terhadap Teknologi Sebagai Pendukung Pembelajaran di Pondok Pesantren Salaf
}

\author{
Athiyatul Ulya ${ }^{a *}$, Feby Artwodini Muqtadiroh ${ }^{b}$, Ahmad Muklason $^{c}$ \\ ${ }^{a b c}$ Departemen Sistem Informasi, Institut Teknologi Sepuluh Nopember, Sukolilo, Surabaya 60111, Indonesia
}

\section{INFORMASI ARTIKEL}

Sejarah Artikel:

Diterima Redaksi: 13 November 2020

Revisi Akhir: 07 Februari 2021

Diterbitkan Online: 30 Mei 2021

\section{KATA KUNCI}

Faktor Resistansi Guru,

Teknologi Pendukung Pembelajaran,

Pondok Pesantren Salaf,

Local Wisdom

\section{KORESPONDENSI}

E-mail: athiyatul.ulya16@mhs.is.its.ac.id*

\section{PENDAHULUAN}

Dewasa ini cara pondok pesantren untuk menyikapi perubahan teknologi dapat dikategorikan menjadi pondok pesantren kholaf dan pondok pesantren salaf. Pondok pesantren salaf adalah pondok pesantren yang tetap mempertahankan tradisi klasik dan menolak modernitas. Ada juga pesantren yang lebih terbuka terhadap perubahan dengan mengambil jalan tengah, yaitu tetap mempertahankan tradisi klasik yang masih baik dan tidak menolak perubahan modernitas yang lebih baik, atau lebih dikenal dengan sebutan pondok pesantren salaf [1]. Pondok Pesantren Fathul Ulum Kwagean adalah salah satu pondok pesantren salaf terkemuka di Indonesia yang berlokasi di Krenceng Kepung Pare, Kabupaten Kediri, Propinsi Jawa Timur.
Pondok Pesantren Fathul Ulum Kwagean adalah lembaga pendidikan berakidah islam yang berpaham Ahlus Sunnah wal Jama'ah bertujuan untuk membentuk insan berilmu, beramal, berakhlak mulia dan masyarakat islami. Pondok Pesantren Fathul Ulum menyelenggarakan program-program pendidikan madrasah formal dan nonformal, pengajian, kursus, pelatihan dan kegiatan keagamaan serta kegiatan sosial masyarakat [2].

Memasuki era Education 4.0, kemajuan teknologi yang berkembang pesat berdampak pada berubahnya metode pengajaran dan pengaturan dalam proses belajar mengajar. Penggunaan teknologi dapat membantu proses pembelajaran agar berjalan lebih efektif. Dengan jumlah santri Pondok Pesantren Fathul Ulum Kwagean yang semakin hari semakin meningkat, para guru tetap mempertahankan tradisi pesantren dengan metode 
pembelajaran tradisional. Dari segi perangkat lunak, belum ada penerapan teknologi informasi yang digunakan oleh guru untuk mendukung proses pembelajaran secara konsisten [3]. Namun demikian, hal ini tidak membuat minat santri untuk menimba ilmu di Pondok Pesantren Fathul Ulum Kwagean menurun. Santri tetap antusias mengikuti pembelajaran di pondok pesantren meskipun metode yang digunakan dalam proses pembelajaran masih menggunakan metode ceramah. Di sisi lain, para guru masih enggan untuk menggunakan teknologi sebagai media pendukung proses pembelajaran.

Beberapa penelitian sebelumnya telah dilakukan untuk menggali faktor penolakan pengguna terhadap teknologi. Menurut Reginia Mia Saraswati dalam penelitiannya untuk mengetahui faktor yang memengaruhi penolakan dosen terhadap adopsi Share ITS, perceived threat dan perceived usefulness merupakan salah faktor yang memengaruhi rendahnya niat dosen dalam menggunakan Share ITS secara berkelanjutan [4]. Selanjutnya dalam penelitian untuk menganalisis hubungan antara resistansi konsumen dan berbagai faktor dari inovasi dan karakteristik konsumen disebutkan bahwa motivasi, self-efficacy, dan nilai tradisi dalam masyarakat merupakan faktor yang memengaruhi resistansi konsumen [5].

Pada tahun 1981, terlahir sebuah model yang menyebutkan bahwa faktor habit/behavior dan perceived risk berpengaruh terhadap resistansi teknologi yakni dikenal dengan model Sheth. Selanjutnya dikembangkan model Ram yang menyatakan bahwa perceived innovation characteristics, consumers characteristics, dan characteristics of propagation mechanisms dapat memengaruhi resistansi pengguna terhadap teknologi. Pada tahun 1989, Davis mengembangkan model muncul technological acceptance model (TAM. Menurut model TAM, niat seseorang untuk menggunakan teknologi dipengaruhi oleh faktor perceived usefulness dan faktor perceived ease of use. Selanjutnya Yu dan Lee melakukan modifikasi terhadap model Ram pada tahun 1994. Mereka mengatakan bahwa hanya faktor innovation characteristics dan consumer characteristics berpengaruh terhadap resistansi pengguna terhadap teknologi [6]. Namun demikian, tidak ada penelitian maupun model spesifik yang dikembangkan untuk pondok pesantren. Sistem pendidikan pondok pesantren yang menggabungkan sistem pendidikan umum dengan sistem pendidikan agama menjadikan pondok pesantren sebagai sebuah fenomena yang unik dan berbeda dari yang lain.

Berdasarkan permasalahan di atas, penulis ingin menggali faktor resistansi guru terhadap teknologi informasi sebagai pendukung pembelajaran. Penelitian ini dilakukan dengan menggunakan metode penelitian kualitatif mengingat belum ada model yang secara spesifik dikembangkan untuk menggali faktor resistansi teknologi di pondok pesantren. Data yang digunakan berasal dari hasil kuesioner dan proses wawancara serta observasi yang dilakukan secara langsung di pondok pesantren. Setelah mendapatkan data, peneliti akan menggunakan aplikasi pengolah data kualitatif untuk meneliti faktor-faktor resistansi guru terhadap teknologi. Faktor-faktor tersebut selanjutnya akan dikelompokkan menjadi kategori faktor resistansi teknologi bersadarkan kemiripan yang dimiliki oleh setiap faktor. Penelitian ini bermaksud untuk menghasilkan luaran berupa usulan faktor resistansi guru terhadap penggunaan teknologi informasi dalam proses pembelajaran. Harapannya, penelitian ini dapat membantu pondok pesantren untuk menemukan faktor yang menjadi penyebab resistansi teknologi. Penulis juga berharap penelitian ini dapat meningkatkan kualitas pembelajaran di Pondok Pesantren Fathul Ulum Kwagean.

Beberapa penelitian yang berkaitan dengan penelitian ini adalah The Innovation in Education of Islamic Boarding School Through The Use of E-Learning [7] yang mengkaji tentang penggunaan teknologi e-learning di pondok pesantren pada tingkat perguruan tinggi, sedangkan penelitian ini mengkaji tentang resistansi teknologi pada tingkat sekolah. Selanjutnya penelitian Blended Learning dari Perspektif Para Guru Sekolah di Pondok Pesantren [1] yang mengkaji tentang penerimaan teknologi dilihat dari perspektif guru di pondok pesantren kholaf, perbedaanya adalah penelitian ini berfokus pada pondok pesantren salaf. Selanjutnya penelitian Analisis Faktor Penolakan Dosen Dalam Adopsi Share ITS [4] dimana tujuannya adalah mengidentifikasi faktor-faktor penolakan guru terhadap penggunaan teknologi dalam proses pembelajaran, perbedaannya adalah penelitian ini berfokus pada pondok pesantren. Selanjutnya penelitian Terakhir penelitian Factors Affecting Consumer Resistance to Innovation in Mobile Phone Industry [5] yang menggunakan metode penelitian gabungan untuk memperoleh faktor-faktor yang memengaruhi penolakan inovasi ponsel. Penelitian ini juga menggunakan metode penelitian gabungan untuk menemukan faktor-faktor penolakan teknologi dalam proses pembelajaran, perbedaannya adalah penelitian ini berfokus pada resistansi teknologi dilihat dari perspektif guru. Perbandingan dari tiap penelitian dan kaitannya dengan penelitian ini dapat dilihat pada Tabel 1 .

Tabel 1. Perbandingan dengan Penelitian Sebelumnya

\begin{tabular}{|c|c|}
\hline & Perbandingan \\
\hline Penelitian 1 & $\begin{array}{l}\text { Penelitian } 1 \text { mengkaji tentang penggunaan } \\
\text { teknologi e-learning di pondok pesantren pada } \\
\text { tingkat perguruan tinggi. Sedangkan penelitian ini } \\
\text { berfokus kepada penggunaan teknologi di pondok } \\
\text { pesantren salafiyah dimana pondok pesantren } \\
\text { tersebut belum menggunakan dan cenderung } \\
\text { menolak penggunaan teknologi. }\end{array}$ \\
\hline Penelitian 2 & $\begin{array}{l}\text { Penelitian } 2 \text { mengkaji tentang penerimaan } \\
\text { teknologi dilihat dari perspektif guru di pondok } \\
\text { pesantren kholaf. Sedangkan penelitian mengkaji } \\
\text { tentang resistansi penggunaan teknologi di } \\
\text { pondok pesantren salaf dilihat dari perspektif } \\
\text { guru-guru yang mengajar mata pelajaran salaf di } \\
\text { pondok pesantren. }\end{array}$ \\
\hline Penelitian 3 & $\begin{array}{l}\text { Penelitian } 1 \text { mengidentifikasi faktor-faktor } \\
\text { resistansi guru terhadap penggunaan teknologi } \\
\text { dalam proses pembelajaran dengan menggunakan } \\
\text { model penelitian yang dikembangkan oleh Lin, } \\
\text { Chihung, I-Chun Lin, dan Jinsheng Roan. } \\
\text { Sedangkan penelitian ini menggunakan metode } \\
\text { penelitian kualitatif untuk menemukan faktor- } \\
\text { faktor khas dan unik yang hanya dimiliki oleh } \\
\text { pondok pesantren. }\end{array}$ \\
\hline Penelitian 4 & $\begin{array}{l}\text { Penelitian } 4 \text { mengkaji faktor-faktor yang } \\
\text { memengaruhi resistansi inovasi ponsel. } \\
\text { Sedangkan penelitian ini berfokus pada faktor- } \\
\text { faktor resistansi terhadap teknologi pendukung } \\
\text { pembelajaran di pondok pesantren. }\end{array}$ \\
\hline
\end{tabular}


Revolusi industri 4.0 telah memberikan dampak yang besar terhadap segala aspek kehidupan masyarakat saat ini. Education 4.0 adalah salah satu imbas dari revolusi industri 4.0 dimana manusia dan teknologi dituntut selaras untuk untuk menghasilkan kemungkinan baru dalam dunia pendidikan [8]. Education 4.0 mengusung konsep yang sangat mengutamakan siswa dalam proses belajar mengajar. Siswa belajar bersama dan dari satu sama lain. Guru hanya akan berperan sebagai fasilitator yang akan membantu siswa yang kesulitan selama proses pembelajaran. Berikut adalah kecenderungan yang terjadi dalam Education 4.0 [9]

1) Pembelajaran dapat dilakukan dimana dan kapan saja.

2) Pembelajaran akan disesuaikan dengan setiap individu.

3) Siswa dapat menentukan bagaimana mereka ingin belajar.

4) Pembelajaran berbasis proyek

5) Pengalaman lapangan.

6) Interpretasi data.

7) Ujian akan berubah.

8) Kepemilikan siswa.

9) Mentoring akan menjadi lebih penting.

Teknologi Pendidikan merupakan metode bersistem yang dirancang untuk merencanakan, menggunakan, dan menilai seluruh kegiatan pengajaran dan pembelajaran dengan memerhatikan, baik sumber teknis maupun manusia dan interaksi antara keduanya, sehingga mendapatkan bentuk pendidikan yang lebih efektif [10].

Pada dasarnya, pemanfaatan teknologi sebagai media pembelajaran baik secara langsung maupun tidak langsung mengacu kepada e-learning [11]. Namun, dalam hal ini, teknologi yang dimaksud sebagai media pendukung pembelajaran disesuaikan dengan kondisi eksisting sistem pendidikan di pondok pesantren yang menjadi studi kasus penelitian ini. Menurut hasil penyebaran kuesioner, diketahui bahwa sebagian besar teknologi yang saat ini dibutuhkan di pondok pesantren antara lain seperti Microsoft Word, Microsoft Excel, Microsoft PowerPoint, Google Drive, Google Docs dan Google Classroom.

Dalam melakukan penelitian, terdapat banyak sekali metode yang dapat digunakan. Namun demikian, metode penelitian biasanya dibedakan menjadi penelitian kuantitatif dan penelitian kualitatif. Penelitian kualitatif adalah suatu metode penelitian yang dikembangkan untuk memungkinkan peneliti menggali permasalahan dari sisi fenomena sosial dan budaya [12]. Penelitian kualitatif merupakan metode penelitian yang mengandalkan data teks dan gambar, memiliki langkah-langkah yang unik dalam menganalisis data, dan diambil dari desain yang beragam [13].

Dalam melakukan penelitian kualitatif, terdapat beberapa metode yang dapat digunakan. Metode penelitian kualitatif yang umum digunakan yaitu penelitian tindakan yang ditujukan untuk memberikan kontribusi pada pemecahan masalah dalam situasi yang problematik [14], penelitian studi kasus yang relevan diterapkan untuk mempelajari fenomena yang tampaknya tidak dapat dipisahkan dari konteksnya, etnografi yang sangat menekankan pada pengamatan terhadap sekelompok orang dengan lingkungan yang alamiah [15], dan grounded theory yang berupaya mengembangkan teori yang didasarkan pada data yang dikumpulkan dan dianalisis secara sistematis. Dalam pengerjaan

20 Athiyatul Ulya penelitian ini, penulis menggunakan metode penelitian kualitatif gabungan.

Resistansi terhadap teknologi dapat disebabkan oleh berbagai macam alasan. Beberapa faktor yang melatar belakangi resistansi masyarakat terhadap teknologi antara lain seperti rendahnya motivasi pengguna untuk menggunakan teknologi [16], hambatan penggunaan teknologi seperti usage, value, risk, image dan tradition barrier [5], usia dan pendidikan [6], nilai tradisi, dukungan manajemen, pendapatan, infrastruktur, serta keterampilan/skill [17]. Penulis berupaya untuk menemukan faktor resistansi teknologi di pondok pesantren, namun belum ditemukan penelitian yang secara spesifik membahas mengenai pondok pesantren.

\section{METODE}

Tahapan yang dilalui dalam penelitian, pembangunan konsep, atau penyelesaian kasus, dituliskan pada bagian metodologi. Pada Gambar 1 berikut ditunjukkan uraian tahapan pelaksanaan yang dilakukan selama penelitian ini berlangsung.

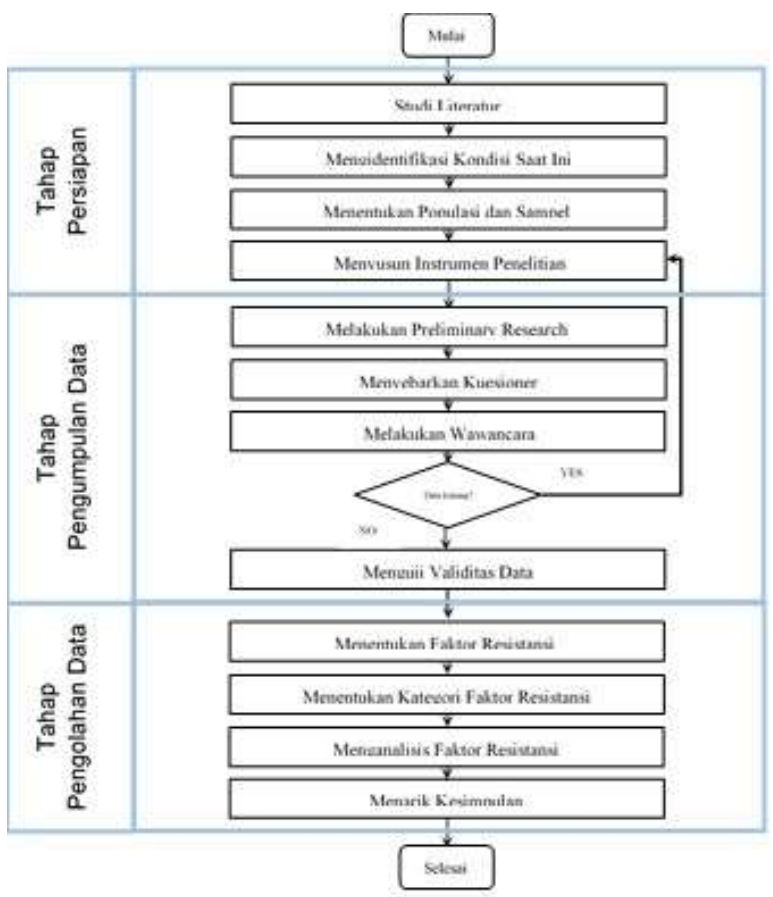

Gambar 1. Metodologi Penelitian

\subsection{Tahap Persiapan}

Tahap persiapan merupakan tahapan pertama yang dilakukan dalam pelaksanaan penelitian ini. Pada tahap persiapan dilakukan tahap studi literatur untuk membuka wawasan dan menambah acuan penelitian. Selanjutnya dilakukan tahap identifikasi kondisi saat ini, menentukan populasi dan sampel serta menyusun instrumen penelitian.

\subsubsection{Populasi dan Sampel}

Dari 11 lembaga pendidikan yang dinaungi oleh Pondok Pesantren Fathul Ulum Kwagean, secara keseluruhan semua lembaga kecuali Madrasah Ibtidaiyah Futuhiyyah dan TK Kusuma Mulia masih menggunakan sistem pendidikan tradisional seperti sorogan dan bandongan. Sehingga yang 
menjadi fokus dalam penelitian ini adalah guru-guru yang menjadi pengajar di 9 lembaga salaf tersebut. Populasi seluruh guru di Pondok Pesantren Fathul Ulum Kwagean adalah sebanyak 200 orang guru. Guru yang mengajar di 9 lembaga pendidikan yang dijadikan sebagai objek penelitian berjumlah 176 orang guru. Sehingga jumlah populasi untuk penelitian ini adalah 176 orang. Selanjutnya responden ditentukan menggunakan metode random sampling dan penentuan jumlah sampel ditentukan menggunakan rumus slovin. Rumus slovin digunakan untuk menentukan ukuran sampel minimal berupa (n) dengan populasi berupa $(\mathrm{N})$ dengan batas kesalahan (e) sebesar $10 \%$ [18]. Berdasarkan perhitungan tersebut, didapatkan bahwa jumlah minimal responden yang dibutuhkan untuk mengisi kuesioner adalah 64 orang.

\subsubsection{Instrumen Penelitian}

Penelitian kualitatif dapat dilakukan dengan menggunakan beberapa jenis instrumen penelitian. Instrumen yang akan digunakan pada penelitian ini berupa kuesioner dan interview protocol yang dibutuhkan untuk pengambilan data melalui wawancara dengan narasumber. Instrumen selanjutnya yang juga berperan penting dalam penelitian kualitatif adalah peneliti dimana peneliti akan berperan sebagai pengamat. Peneliti berfungsi untuk menetapkan fokus penelitian, memilih informan yang akan dijadikan narasumber, mengumpulkan data, menilai kualitas data yang telah dikumpulkan, menafsirkan dan menganalisis data serta menarik kesimpulan dari apa yang ditemukan selama penelitian [19].

Kuesioner dibutuhkan untuk mengetahui respons guru terhadap penggunaan teknologi. Proses penyebaran kuesioner akan dilakukan secara daring dalam bentuk Google Form kepada sekitar 100 guru dari 9 lembaga target. Jawaban-jawaban yang diberikan akan digunakan untuk menyaring subjek penelitian sehingga akan muncul subjek penelitian yang cenderung resistan terhadap penggunaan teknologi. Selanjutnya penelitian akan berfokus kepada subjek-subjek yang sudah disaring tersebut.

Pembuatan kuesioner dilakukan dengan menggunakan skala likert dengan rentang 1 (sangat tidak setuju) sampai 4 (sangat setuju) serta beberapa pertanyaan semi terbuka dan pertanyaan terbuka. Kuesioner ditujukan untuk mengetahui siapa saja guru yang menolak, tidak tertarik atau bahkan enggan menggunakan teknologi serta alasan mereka menolak teknologi.

Interview protocol akan digunakan saat melakukan wawancara dengan responden yang memenuhi kriteria purposive sampling yakni responden terpilih yang lulus penyaringan. Hal ini dilakukan untuk mengetahui dan menggali lebih dalam alasan responden menolak penggunaan teknologi untuk mendukung proses pembelajaran. Interview protocol terdiri dari beberapa pertanyaan terbuka yang dibagi berdasarkan faktor resistansi. berkaitan dengan setiap faktor resistansi.

\subsection{Tahap Pengumpulan Data}

Tahap selanjutnya yang dilakukan setelah tahap persiapan adalah tahap pengumpulan data. Tahap ini bertujuan untuk menggali data dan informasi terkait situasi penerapan teknologi di pondok pesantren. Tahap pengumpulan data diawali dengan pelaksanaan preliminary research untuk memastikan kondisi dan situasi terkini pondok pesantren. Selanjutnya dilakukan penyebaran kuesioner dan pelaksanaan wawancara. Setelah data yang dibutuhkan terkumpul, dilakukan pengujian untuk mengetahui tingkat validitas dan reliabilitas data.

\subsubsection{Strategi Pengumpulan Data}

Strategi pengambilan data yang digunakan dalam penelitian ini adalah berupa penyebaran kuesioner dan wawancara dengan informan terpilih. Penyebaran kuesioner yang digunakan untuk menyaring responden yang sesuai dengan kriteria yang diinginkan. Selanjutnya akan dilakukan wawancara untuk menggali lebih dalam mengenai resistansi guru terhadap penggunaan teknologi.

Kuesioner akan disebarkan kepada sejumlah guru yang mengajar di pondok salaf. Dalam hal ini kuesioner akan diberikan kepada pihak narahubung dari pondok pesantren untuk selanjutnya disebarkan kepada guru-guru yang bersangkutan. Hasil dari kuesioner akan digunakan untuk menyaring subjek penelitian sehingga akan muncul subjek penelitian yang memiliki resistansi terhadap penggunaan teknologi. Sehingga penelitian dapat berfokus kepada guru yang cenderung resistan terhadap penggunaan teknologi dan dapat dipercaya untuk dijadikan sebagai narasumber. Responden yang terpilih yakni guru yang cenderung resistan terhadap penggunaan teknologi selanjutnya akan dijadikan narasumber dalam pelaksanaan wawancara. Proses wawancara dilakukan untuk menggali lebih dalam mengenai alasan narasumber resistan terhadap teknologi.

\subsection{Tahap Pengolahan Data}

Data yang telah dikumpulkan dan diuji validitas dan reliabilitasnya selanjutnya diolah pada tahap pengolahan data. Pengolahan data diawali dengan menemukan faktor resistansi guru terhadap teknologi. Faktor yang ditemukan selanjutnya akan dikelompokkan menjadi beberapa kategori berdasarkan kemiripan dan kedekatan faktor. Selanjutnya dilakukan analisis keterkaitan faktor hingga pengambilan kesimpulan berupa hasil faktor resistansi guru terhadap teknologi.

\section{HASIL DAN PEMBAHASAN}

\subsection{Profil Pondok Pesantren}

Pondok pesantren tempat dilaksanakannya penelitian ini adalah Pondok Pesantren Fathul Ulum Kwagean yang berlokasi di Krenceng Kepung Pare, Kabupaten Kediri, Propinsi Jawa Timur. Pondok Pesantren Fathul Ulum adalah lembaga pendidikan berakidah islam yang berpaham Ahlus Sunnah wal Jama'ah dan bertujuan untuk membentuk insan berilmu, beramal, berakhlak mulia dan masyarakat islami. Pondok Pesantren Fathul Ulum menyelenggarakan program-program pendidikan madrasah formal dan non-formal, pengajian, kursus, pelatihan dan kegiatan keagamaan serta kegiatan sosial masyarakat [6].

Yayasan Pesantren Fathul Ulum menaungi 13 lembaga yang mencakup 11 lembaga pendidikan dan 2 lembaga perekonomian. Lembaga pendidikan yang dijadikan subjek penelitian adalah lembaga yang masih menggunakan sistem pendidikan tradisional seperti sorogan dan bandongan yakni Pondok Putra Pesantren Fathul Ulum, Pondok Putri Pesantren Fathul Ulum, Pondok An Nur Pesantren Fathul Ulum, Pondok Al Anwar Pesantren Fathul Ulum, Madrasah Diniyah Futuhiyyah, Madrasah Quraniyyah Futuhiyyah, Pondok As Salam Pesantren Fathul Ulum, Pondok

Athiyatul Ulya

21 
Al Fatih Pesantren Fathul Ulum, dan Madin Formal Al Munawworah.

\subsection{Profil Responden}

Responden yang dipilih adalah orang yang mengetahui secara jelas mengenai fakta dan kebenaran yang terjadi di lokasi penelitian. Responden harus dapat memberikan penjelasan sesuai dengan keadaan yang ada. Responden pada penelitian ini adalah guru-guru yang mengajar di 9 lembaga pendidikan yang menerapkan sistem pendidikan salaf. Penyebaran kuesioner dilakukan secara daring kepada kepada sekitar 100 guru dari 9 lembaga target. Namun, kuesioner hanya diisi oleh 30 orang responden karena adanya kendala yakni terbatasnya penggunaan perangkat elektronik di pondok pesantren. Berikut adalah daftar responden yang dianggap dapat mewakili responden yang resistan terhadap teknologi.

Tabel 2. Daftar Responden

\begin{tabular}{|c|c|c|c|c|}
\hline Responden & $\begin{array}{c}\text { Jenis } \\
\text { Kelamin }\end{array}$ & Usia & Pendidikan & Lama Mengajar \\
\hline 1 & Perempuan & 21-30 tahun & $\mathrm{S} 1$ & $<5$ tahun \\
\hline 2 & Laki-laki & 21-30 tahun & MA Sederajat & $<5$ tahun \\
\hline 3 & Perempuan & 21-30 tahun & MA Sederajat & $<5$ tahun \\
\hline 4 & Perempuan & 21-30 tahun & MA Sederajat & $<5$ tahun \\
\hline 5 & Laki-laki & 21-30 tahun & MA Sederajat & $<5$ tahun \\
\hline 6 & Laki-laki & $<21$ tahun & MA Sederajat & $<5$ tahun \\
\hline 7 & Laki-laki & 21-30 tahun & MA Sederajat & 5-10 tahun \\
\hline 8 & Laki-laki & 21-30 tahun & MI Sederajat & 5-10 tahun \\
\hline 9 & Laki-laki & 21-30 tahun & MA Sederajat & $<5$ tahun \\
\hline 10 & Laki-laki & 21-30 tahun & MA Sederajat & $<5$ tahun \\
\hline 11 & Perempuan & $<21$ tahun & MA Sederajat & $<5$ tahun \\
\hline 12 & Laki-laki & 21-30 tahun & MTS Sederajat & 11-20 tahun \\
\hline 13 & Laki-laki & 21-30 tahun & MA Sederajat & 5-10 tahun \\
\hline 14 & Laki-laki & 21-30 tahun & MI Sederajat & 5-10 tahun \\
\hline 15 & Laki-laki & 21-30 tahun & MTS Sederajat & 5-10 tahun \\
\hline 16 & Laki-laki & 21-30 tahun & MA Sederajat & 5-10 tahun \\
\hline 17 & Perempuan & $<21$ tahun & Tidak bersekolah & $<5$ tahun \\
\hline 18 & Laki-laki & 21-30 tahun & MA Sederajat & $<5$ tahun \\
\hline 19 & Laki-laki & 21-30 tahun & D3 & 5-10 tahun \\
\hline 20 & Perempuan & 21-30 tahun & MA Sederajat & $<5$ tahun \\
\hline 21 & Laki-laki & 31- 40 tahun & S1 & 11-20 tahun \\
\hline 22 & Laki-laki & 21-30 tahun & MA Sederajat & $<5$ tahun \\
\hline 23 & Laki-laki & 21-30 tahun & MA Sederajat & $<5$ tahun \\
\hline 24 & Perempuan & 21-30 tahun & MA Sederajat & $<5$ tahun \\
\hline 25 & Laki-laki & 21-30 tahun & MTS Sederajat & $<5$ tahun \\
\hline 26 & Laki-laki & $<21$ tahun & MA Sederajat & $<5$ tahun \\
\hline 27 & Laki-laki & $<21$ tahun & MA Sederajat & $<5$ tahun \\
\hline 28 & Laki-laki & 21-30 tahun & MTS Sederajat & $<5$ tahun \\
\hline 29 & Laki-laki & 21-30 tahun & MTS Sederajat & $<5$ tahun \\
\hline 30 & Laki-laki & 21-30 tahun & MTS Sederajat & $<5$ tahun \\
\hline
\end{tabular}

\subsection{Pengumpulan Data}

Sebelum dilakukan proses pengumpulan data, terlebih dahulu dilakukan preliminary research untuk memastikan mengenai kondisi terkini di pondok pesantren yang telah didapatkan dari studi dokumentasi sebelumnya. Pengumpulan data dilakukan dengan cara menyebarkan kuesioner dan dengan wawancara. Proses penyebaran kuesioner kepada guru dari 9 lembaga target dilakukan secara daring dengan bantuan narahubung yakni salah satu dewan pengasuh di pondok pesantren. Kuesioner yang dibagikan adalah kuesioner online dalam bentuk Google Form. Kuesioner mulai disebarkan pada tanggal 7 Mei 2020 hingga tanggal 7 Juni 2020 kepada sekitar 100 guru dari 9 lembaga target. Menurut narahubung, sebagian besar guru telah dipulangkan dan tidak berada di pondok pesantren sehingga sulit dihubungi, sebagian guru tidak memberikan tanggapan, serta guru-guru yang sudah sepuh tidak memungkinkan untuk mengisi kuesioner sehingga selama proses pengumpulan data melalui kuesioner, responden yang mengisi kuesioner berjumlah 30 orang. Proses wawancara secara langsung tidak memungkinkan untuk dilakukan mengingat kondisi dan situasi ditengah pandemi Covid19. Penulis mencoba untuk melakukan wawancara secara daring namun terkendala karena terbatasnya akses perangkat elektronik di pondok pesantren. Guru-guru yang ingin diwawancarai sibuk dengan kegiatan pondok pesantren yang sudah mulai aktif. Sebagian guru ada yang tidak membawa peralatan elektronik ke lingkungan pondok pesantren sehingga tidak dapat dihubungi.

\subsection{Uji Validitas dan Reliabilitas Data}

Pengujian validitas kuesioner dilakukan dengan menggunakan korelasi Bivariate Pearson atau lebih dikenal dengan Produk Momen Pearson. Nilai tabel - $r$ yang digunakan pada pengujian ini dimana tingkat signifikansi sebesar 0,05 dengan nilai n sebesar 30 adalah 0,361. Hasil uji validitas kuesioner yang dilakukan dengan menggunakan bantuan software SPSS 24 menyatakan bahwa seluruh item pernyataan yang terdapat pada kuesioner telah valid karena nilai pearson correlation setiap item pernyataan lebih besar dari nilai tabel -r. Sehingga dapat 
disimpulkan bahwa data hasil kuesioner valid dan layak untuk digunakan.

Pengujian reliabilitas kuesioner dilakukan dengan menggunakan rumus Cronbach Alpha. Sebuah data dapat dikatakan reliabel apabila memiliki nilai Cronbach Alpha lebih dari atau sama dengan 0,6. Hasil uji reliabilitas yang dilakukan dengan menggunakan bantuan software SPSS 24 menyatakan bahwa hasil uji reliabilitas yang dilakukan pada setiap item pernyataan kuesioner adalah 0,944 yaitu lebih dari 0,6 sehingga dapat disimpulkan bahwa data yang didapatkan dari kuesioner telah reliabel.

\subsection{Faktor Resistansi}

Data dari ketujuh responden tersebut selanjutnya dianalisis menggunakan aplikasi pengolah data kualitatif NVIVO 12 untuk menemukan kata kunci yang kemudian dijadikan faktor resistansi. Berdasarkan hasil pengolahan data, didapatkan bahwa ada 16 faktor yang menyebabkan resistansi guru terhadap teknologi dan 1 faktor tambahan yang didapatkan dari demografi responden. Sehingga didapatkan total faktor resistansi guru terhadap teknologi sebanyak 17 faktor. Masing-masing faktor diwakili oleh sebuah node yang menunjukkan persentase cakupan atau coverage masing-masing faktor. Berikut adalah faktor-faktor resistansi terhadap teknologi dilihat dari sudut pandang guru di Pondok Pesantren Fathul Ulum Kwagean.

1) Faktor kebijakan pesantren adalah faktor yang paling banyak muncul yakni sebanyak 19 references coded dengan angka coverage sebesar $8.16 \%$.

2) Faktor fasilitas pendukung disebutkan dalam 16 references coded dengan angka coverage $6.29 \%$.

3) Faktor kemampuan teknis muncul sebanyak 13 references coded dengan angka coverage sebesar $5.41 \%$.

4) Faktor dukungan manajemen muncul sebanyak 11 references coded dengan angka coverage sebesar $4.99 \%$.

5) Faktor kesulitan penggunaan teknologi muncul sebanyak 11 references coded dengan angka coverage sebesar $4.31 \%$.

6) Faktor hambatan dalam penggunaan teknologi muncul sebanyak 6 references coded dengan angka coverage sebesar $2.17 \%$.

7) Faktor motivasi pengguna muncul sebanyak 6 references coded dengan angka coverage sebesar $2.43 \%$.

8) Faktor keraguan manfaat teknologi muncul sebanyak 6 references coded dengan angka coverage sebesar $2.64 \%$.

9) Faktor kemampuan akademik muncul sebanyak 5 references coded dengan angka coverage sebesar $1.79 \%$.

10) Faktor penurunan performa muncul sebanyak 5 references coded dengan angka coverage sebesar $1.48 \%$.

11) Faktor tradisi pesantren muncul sebanyak 3 references coded dengan angka coverage sebesar $0.91 \%$.

12) Faktor ekonomi muncul sebanyak 2 references coded dengan angka coverage sebesar $0.83 \%$.

13) Faktor penurunan kualitas pendidikan muncul sebanyak 1 references coded dengan angka coverage sebesar $0.48 \%$.

14) Faktor sosial budaya muncul sebanyak 1 references coded dengan coverage sebesar $0.26 \%$.

15) Faktor kesehatan muncul sebanyak 1 references coded dengan coverage sebesar $0.25 \%$.

16) Faktor ketidakcocokan teknologi dengan pesantren muncul sebanyak 1 references coded dengan angka coverage sebesar $0.16 \%$.

https://doi.org/10.25077/TEKNOSI.v7i1.2021.18-26
17) Faktor usia dan pendidikan yang didapatkan dari hasil analisis data demografi responden.

\subsection{Faktor Paling Berpengaruh}

Faktor yang paling berpengaruh terhadap resistansi guru terhadap teknologi dapat dilihat dari faktor yang memiliki nilai tingkat cakupan paling besar. Berdasarkan tingkat cakupan setiap faktor, terdapat 3 faktor resistansi guru terhadap teknologi yang paling tinggi nilai tingkat cakupannya. Ketiga faktor tersebut adalah faktor kebijakan pesantren dengan tingkat cakupan sebesar $8.16 \%$, faktor fasilitas pendukung dengan tingkat cakupan sebesar $6.29 \%$ serta faktor kemampuan teknis dengan tingkat cakupan sebesar $5.44 \%$.

\subsection{Kategori Faktor Internal}

Kategori faktor internal merupakan kategori yang berisi faktorfaktor resistansi guru terhadap teknologi yang berasal dari diri pengguna itu sendiri. Berikut adalah faktor-faktor internal penyebab resistansi guru terhadap teknologi.

1) Kemampuan Teknis

2) Kesulitan Penggunaan TI

3) Keraguan Manfaat TI

4) Motivasi Pengguna

5) Hambatan Penggunaan TI

6) Kemampuan Akademik

7) Penurunan Performa

8) Ekonomi

9) Penurunan Kualitas Pendidikan

10) Kesehatan

11) Usia dan Pendidikan

\subsection{Kategori Faktor Eksternal}

Kategori faktor eksternal merupakan kategori yang berisi faktorfaktor resistansi guru terhadap teknologi yang berasal dari luar diri pengguna seperti dari lingkungan dan orang-orang sekitar pengguna. Berikut adalah faktor-faktor eksternal penyebab resistansi guru terhadap teknologi.

1) Kebijakan Pesantren

2) Fasilitas Pendukung

3) Dukungan Manajemen

4) Tradisi Pesantren

5) Sosial Budaya

6) Ketidakcocokan TI dengan Pesantren

\subsection{Kategori Faktor Berdasarkan Kedekatan}

Selanjutnya 17 faktor resistansi yang telah didapatkan dapat dikelompokkan ke dalam beberapa kategori berdasarkan kedekatan dan kemiripan kata-kata yang dimilki oleh setiap faktor. Pengelompokan faktor-faktor resistansi dilakukan menggunakan analisis cluster dengan bantuan aplikasi pengolah data kualitatif NVIVO 12. Kategori faktor berdasarkan kedekatan ditunjukkan pada Gambar 2. 


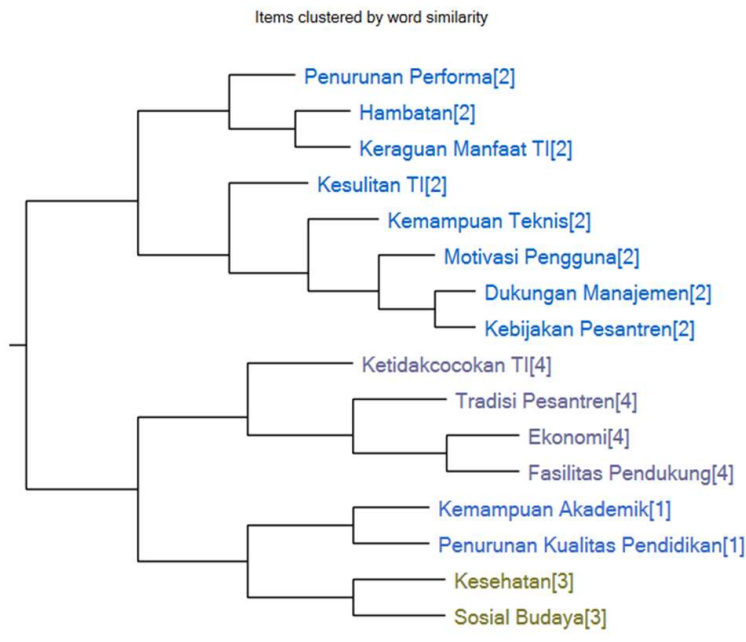

Gambar 2. Kategori Faktor Resistansi

Pada Gambar 2 terdapat 4 ID Cluster yang muncul setelah dilakukan clustering by word similarity. Sehingga dapat disimpulkan bahwa terdapat 4 kategori faktor resistansi. Berikut adalah hasil kategori faktor resistansi guru terhadap teknologi.

1) Kategori Pendidikan

Kategori pendidikan mencakup faktor kemampuan akademik, faktor penurunan kualitas pendidikan serta faktor usia dan pendidikan. Kedua faktor resistansi ini sama-sama membicarakan tentang kekhawatiran pengguna bahwa penggunaan teknologi akan menurunkan kemampuan mereka dalam mengajar yang akan berakibat pada menurunnya kualitas pendidikan di pondok pesantren.

2) Kategori Motivasi Pengguna

Kategori motivasi pengguna meliputi 8 faktor resistansi teknologi yakni faktor kebijakan pesantren, faktor dukungan manajemen, faktor motivasi pengguna, faktor kemampuan teknis, faktor kesulitan teknologi, faktor keraguan manfaat teknologi, faktor hambatan penggunaan teknologi dan faktor penurunan performa. Rendahnya motivasi pengguna terhadap teknologi dapat dipengaruhi oleh faktor internal dan faktor eksternal. Kebijakan pesantren yang melarang penggunaan teknologi dan manajemen yang tidak mendukung penggunaan teknologi merupakan faktor eksternal. Kemampuan teknis pengguna yang rendah menyebabkan pengguna mengalami kesulitan saat menggunakan teknologi. Kesulitan tersebut menyebakan performa pengguna saat menggunakan teknologi menurun sehingga pengguna merasa bahwa teknologi tidak bermanfaat bagi mereka. Hambatan-hambatan yang dirasakan oleh pengguna tersebut akhirnya menyebabkan pengguna tidak memiliki keinginan untuk menggunakan teknologi. Faktor-faktor tersebut adalah faktor internal yakni faktor yang berasal dari pengguna itu sendiri.

3) Kategori Kesehatan \& Sosial Budaya

Kategori kesehatan dan sosial budaya mencakup faktor kesehatan dan faktor sosial budaya. Kekhawatiran responden akan timbulnya kesenjangan sosial dan terganggunya kesehatan mereka apabila terlalu sering menggunakan teknologi menjadi alasan mereka resistan terhadap teknologi.

4) Kategori Tradisi, Infrastruktur \& Ekonomi

Kategori tradisi, infrastruktur dan ekonomi meliputi faktor tradisi pesantren, faktor ketidakcocokan teknologi, faktor fasilitas pendukung dan faktor ekonomi. Pendapatan pesantren yang tidak seberapa mengakibatkan pesantren tidak dapat menyediakan infrastruktur pendukung teknologi. Selain itu, penggunaan teknologi juga dianggap tidak cocok dengan tradisi dan budaya klasikal yang selama ini diterapkan di pondok pesantren.

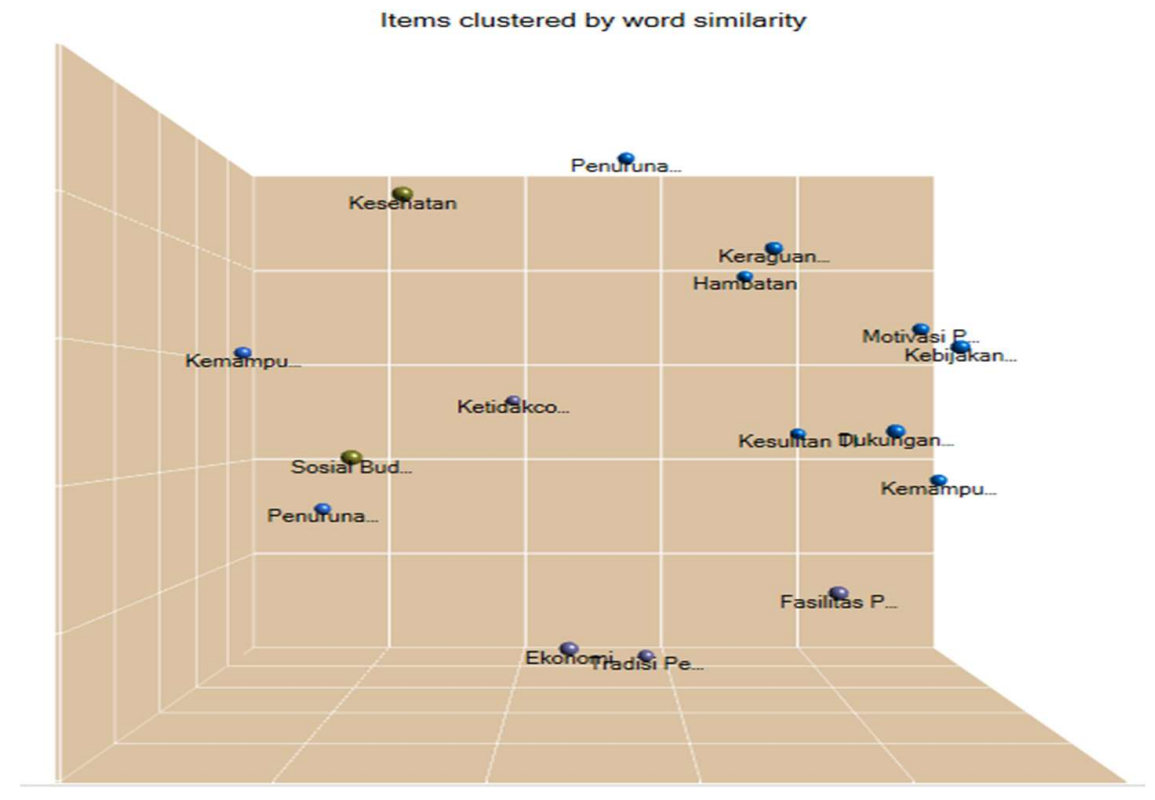

Gambar 3. Cluster Map: Kedekatan Antar Faktor

\subsection{Analisis Faktor Resistansi}

Analisis faktor resistansi yang dilakukan berupa cluster analysis yang digunakan untuk mengelompokkan faktor-faktor resistansi

24 Athiyatul Ulya menjadi kategori faktor resistansi seperti yang sudah dijelaskan pada pembahasan sebelumnya. Cluster analysis juga digunakan untuk melihat kedekatan antar faktor dengan visualisasi berupa cluster map. Analisis cluster dilakukan dengan bantuan aplikasi 
pengolah data kualitatif NVIVO 12. Hasil cluster map ditunjukkan pada Gambar 3.

Pada Gambar 3 terdapat beberapa faktor yang terletak saling berdekatan dan faktor yang terletak berjauhan. Faktor-faktor yang berdekatan tersebut dikelompokkan ke dalam beberapa kategori berdasarkan kedekatan faktor. Kategori yang terbentuk adalah kategori pendidikan, kategori motivasi pengguna, kategori kesehatan \& sosial budaya serta kategori tradisi, infrastruktur dan ekonomi.

Selanjutnya dilakukan wordcloud analysis yang digunakan untuk melihat kata yang paling banyak muncul dan disebutkan oleh responden pada setiap faktor. Wordcloud analysis dilakukan dengan bantuan aplikasi pengolah data kualitatif NVIVO 12 . Visualisasi wordcloud analysis ditunjukkan pada Gambar 4. Pada Gambar 4 ditunjukkan bahwa secara keseluruhan kata paling sering disebutkan oleh responden adalah kata "tidak", "teknologi" dan "pesantren". Kata "tidak" disebutkan sebanyak 64 kali, kata "teknologi" disebutkan sebanyak 58 kali dan kata "pesantren" disebutkan sebanyak 32 kali. Disusul oleh kata "menggunakan" yang disebutkan sebanyak 31 kali. Dari hasil analisis wordcloud ini dapat disimpulkan bahwa teknologi masih memiliki pandangan negatif jika dikaitkan dengan pondok pesantren. Hal ini terlihat dari kata tidak yang paling banyak muncul diikuti oleh kata "teknologi", kata "pesantren" dan kata "menggunakan". Pembahasan mengenai penggunaan teknologi di pondok pesantren memunculkan banyak penolakan yang direpresentasikan oleh kata "tidak".

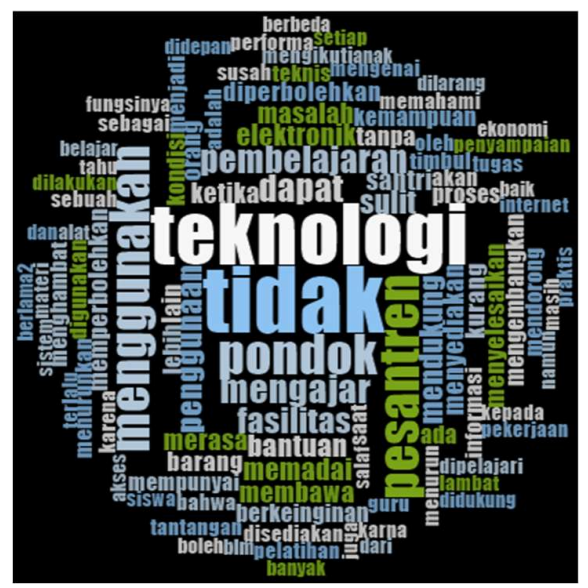

Gambar 4. Wordcloud Analysis

\subsection{Validasi Hasil}

Validasi hasil faktor resistansi guru terhadap teknologi dilakukan dengan cara membandingkan faktor resistansi yang didapatkan dari hasil penelitian dengan faktor resistansi teknologi yang didapatkan dari hasil studi literatur. Hal ini dilakukan untuk memastikan bahwa faktor resistansi yang didapatkan selama penelitian ini telah mencakup semua faktor resistansi yang ada. Proses validasi hasil juga dilakukan untuk memastikan bahwa faktor yang ditemukan sudah valid dan sesuai dengan penelitianpenelitian sebelumnya yang dijadikan sebagai acuan dalam penelitian ini.

\section{KESIMPULAN}

Berdasarkan penelitian mengenai resistansi guru terhadap teknologi yang telah dilakukan untuk mengetahui faktor resistansi guru terhadap teknologi, dapat diambil beberapa kesimpulan bahwa terdapat sejumlah 17 faktor resistansi guru terhadap teknologi di Pondok Pesantren Fathul Ulum Kwagean. Faktor-faktor resistansi tersebut yakni kebijakan pesantren yang tidak memperbolehkan penggunaan teknologi, fasilitas pendukung teknologi yang tidak memadai, kemampuan teknis guru untuk mengoperasikan teknologi yang masih rendah, manajemen yang kurang mendukung penggunaan teknologi, sulitnya penggunaan teknologi yang dirasakan pengguna, pengguna ragu terhadap manfaat TI, motivasi pengguna yang rendah, hambatan dalam penggunaan teknologi, menurunnya kemampuan akademik saat menggunakan teknologi, penurunan performa saat menggunakan teknologi, tradisi pesantren salaf yang dianggap tidak relevan dengan penggunaan teknologi, ekonomi pengguna yang masih rendah, penurunan kualitas pendidikan saat menggunakan teknologi, terjadinya kesenjangan sosial budaya, penurunan kesehatan saat menggunakan teknologi, ketidakcocokan TI dengan pesantren serta usia dan pendidikan responden yang memengaruhi pandangan mereka terhadap penggunaan teknologi.

Berdasarkan tingkat cakupan setiap faktor, terdapat 3 faktor yang paling berpengaruh terhadap resistansi guru terhadap teknologi yakni faktor yang paling tinggi nilai tingkat cakupannya. Ketiga faktor tersebut adalah faktor kebijakan pesantren dengan tingkat cakupan sebesar $8.16 \%$, faktor fasilitas pendukung dengan tingkat cakupan sebesar $6.29 \%$ serta faktor kemampuan teknis dengan tingkat cakupan sebesar 5.44\%. Berdasarkan kedekatan dan kemiripan yang dimiliki oleh setiap faktor, faktor resistansi guru terhadap teknologi di Pondok Pesantren Fathul Ulum Kwagean dapat dikelompokkan menjadi 4 kategori faktor resistansi yakni kategori pendidikan, kategori motivasi pengguna, kategori kesehatan dan sosial budaya serta kategori tradisi, infrastruktur dan ekonomi.

Faktor resistansi guru terhadap teknologi di Pondok Pesantren Fathul Ulum Kwagean dapat dikelompokkan menjadi faktor internal dan faktor eksternal. Faktor internal berisi faktor-faktor yang berasal dari diri pengguna itu sendiri yakni seperti faktor kemampuan teknis, motivasi pengguna, ekonomi, kesehatan serta usia dan pendidikan. Faktor eksternal berisi faktor-faktor resistansi guru terhadap teknologi yang berasal dari luar pengguna seperti faktor kebijakan pesantren, dukungan manajemen, fasilitas pendukung, tradisi pesantren, sosial budaya serta ketidakcocokan TI dengan pesantren.

\section{DAFTAR PUSTAKA}

[1] F. M. W. A. A. D. d. E. R. Ahmad Muklason, "Blended Learning dari Perspektif Para Guru Sekolah di Pondok Pesantren," Jurnal Sistem Informasi, 2019.

[2] "Situs Pondok Fathul Ulum Kwagean," 2020. [Online]. Available:https://www.kwagean.net/pesantren/profilpondok/. [Accessed 7 Juni 2020].

[3] M. Muhammad and D. F. Muhammad, Interviewees, Wawancara Preliminary Research Penggunaan Teknologi 
Pembelajaran di Pondok Pesantren Fathul Ulum Kwagean. [Interview]. 4 Mei 2020.

[4] R. M. Saraswati, Analisis Faktor Penolakan Dosen Dalam Adopsi Share ITS, 2019.

[5] M. D. H. D. d. M. D. Mirza Hassan Hosseini, "Factor Affecting User Resistance to Innovation," International Journal of Asian Social Science, 2016.

[6] K. K. Kim Hyunwoo, "Factors Affecting Consumer Resistance to Innovation: A study of Smartphones," 2009.

[7] A. E. P. H. R Setyaningsih, "The Innovation In Education of Islamic Boarding School Through The Use of E-Learning," 2019.

[8] A. A. Hussin, "Education 4.0 Made Simple: Ideas For Teaching," International Journal of Education \& Literacy Studies, vol. 6, no. 3, 2018.

[9] P. Fisk, "Education 4.0" 24 Januari 2017. [Online]. Available:https://www.thegeniusworks.com/2017/01/future -education-young-everyone-taught-together. [Accessed 11 Nopember 2019].

[10] "Kamus Besar Bahasa Indonesia," Kementerian Pendidikan dan Kebudayaan, 2019. [Online]. Available: http://kbbi.kemdikbud.go.id/. [Accessed 7 October 2019].

[11] S. Naidu, E-Learning: A Guidebook of Principles, Procedures and Practices.

[12] M. D. Myers, "Qualitative Research in Information Systems," MIS Quarterly, pp. 241-242.

[13] J. W. Creswell, Research design: quantitative, qualitative and mixed method approaches, 2014.

[14] M. S, Teori dan Praktik Penelitian Tindakan (Action Research), Bandung: Alfabeta.

[15] "Etnografi," FIP UM, 2015. [Online]. Available: http://fip.um.ac.id/wpcontent/uploads/2015/12/7.4_Etnografi.pdf. [Accessed 05 Nopember 2019].

[16] L. Z. L. M. d. P. 1. Mahmood Ali, "User Resistance in IT : A Literature Review," International Journal of Information Management, 2015.

[17] L. Y. M. d. Z. L. Bergeb, "Student Barriers to Online Learning: A factor analytic study,".

[18] Amirullah, "Populasi dan Sampel (Pemahaman, Jenis, dan Teknik)," in Metode Penelitian Manajemen, Malang, Bayumedia Publishing, 2015, pp. 67 - 80.

[19] J. S. Albi Anggito, in Metodologi Penelitian Kualitatif, Sukabumi, CV Jejak, 2018, pp. 75-78.

\section{BIODATA PENULIS}

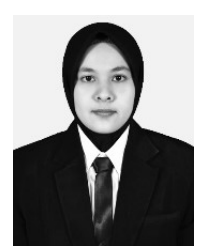

Athiyatul Ulya

Penulis merupakan putri pertama dari tiga bersaudara yang lahir di Aceh pada 14 Maret 1998. Penulis menyelesaikan pendidikan S1 di Departemen Sistem Informasi Institut Teknologi Sepuluh Nopember Surabaya lewat jalur Program Beasiswa Santri Berprestasi dari Kementrian Agama. Penulis mengambil topik penelitian tugas akhir di Laboratorium Manajemen Sistem Informasi terkait resistansi teknologi. Penulis bersertifikasi Oracle Academy Java Fundamentals, dan Certiport ICCC Key Applications.

Feby Artwodini Muqtadiroh
Penulis yang lahir tahun 1983 merupakan lulusan sarjana di Teknik Informatika Institut Teknologi Sepuluh Nopember (ITS) dan magister di STEI ITB. Saat ini menjadi dosen di Departemen Sistem Informasi ITS. Aktif melakukan riset dalam bidang Software Engineering dan E-Learning. Dalam 3 tahun terakhir fokus pada Penelitian Kajian Kebijakan untuk menghasilkan instrumen penjamin kualitas pembelajaran daring ITS. Saat ini menjadi asesor pembelajaran online di bawah Kantor Penjaminan Mutu ITS. Serta aktif dalam kegiatan pengabdian masyarakat melalui implementasi teknologi asistif untuk kaum difabel, serta implementasi teknologi pendukung pembelajaran pada pondok pesantren yang merupakan kearifan lokal nusantara.

\section{Ahmad Muklason}

Menyelesaikan jenjang S1 di Departemen Sistem Informasi Institut Teknologi Sepuluh Nopember pada tahun 2006. Kemudian menyelesaikan pendidikan S2 di Universiti Teknologi PETRONAS Malaysia pada tahun 2009. Selanjutnya menyelesaikan pendidikan S3 di The University of NottinghamUK pada tahun 2017. Fokus bidang penelitian saat ini adalah logika dan struktur data, algoritma dan pemrograman serta optimasi. 